\title{
AWARENESS ON MEDICAL RESEARCH AMONG UNDERGRADUATES IN A TERTIARY TEACHING HOSPITAL: A CROSS SECTIONAL QUESTIONNAIRE BASED STUDY
}

\author{
G. Rajeswarammaํ, D. Aruna Kumari², D. Jayasree3, S. Sharon Sonia4, Y. Vijaya Bhaskar Reddy5 \\ ${ }^{1}$ Assistant Professor, Department of Pharmacology, Kurnool Medical College, Kurnool, Dr. NTRUHS, A. P. \\ ${ }^{2}$ Assistant Professor, Department of Pharmacology, Kurnool Medical College, Kurnool, Dr. NTRUHS, A. P. \\ ${ }_{3}^{3}$ Assistant Professor, Department of Pharmacology, Sri Venkateswara Medical College, Thirupati, Dr. NTRUHS, A. P. \\ ${ }^{4}$ Professor, Department of Pharmacology, Kurnool Medical College, Kurnool, Dr. NTRUHS, A. P. \\ 5Professor \& HOD, Department of Pharmacology, Kurnool Medical College, Kurnool, Dr. NTRUHS, A. P.
}

\section{ABSTRACT}

From the National Council on Undergraduate Research definition, "An inquiry or investigation conducted by an undergraduate student that makes an original intellectual or creative contribution to the discipline." According to a joint statement from the National Conference on Undergraduate Research and the Council on Undergraduate Research (2005): "Undergraduate research is the pedagogy for the 21st century."

\section{AIM}

This study was conducted to assess the awareness, knowledge and attitude of undergraduate students about medical research.

\section{METHODOLOGY}

To conduct this study, we enrolled 235 students from II year MBBS, V and III semester in Kurnool Medical College. Ethical committee approval and oral informed consent was taken. We gave a questionnaire of 25 questions and given enough time to answer the questions.

\section{RESULTS}

Almost $98 \%$ of students think that it is necessary to know about research as an undergraduate; $57 \%$ of students heard about ICMR. Only $10 \%$ of students know about Ethical committee research protocol and inform consent. Only $8 \%$ of students attended conference and $2 \%$ of students presented poster in conference; $3 \%$ of students wrote research protocol; $91 \%$ of students agree that statistics were essential for research. Reasons for not participating in research were lack of awareness (76\%), lack of knowledge (53\%), lack of guidance (90\%), lack of time (33\%), lack of money (40\%) and no need of participating as undergraduate (20\%).

\section{CONCLUSION}

All students were having good awareness and interested to participate in research. All students strongly felt that they need motivation and guidance from their teachers.

\section{KEYWORDS}

Awareness, Knowledge, Medical Research, Undergraduates.

HOW TO CITE THIS ARTICLE: Rajeswaramma G, Kumari DA, Jayasree D, et al. Awareness on medical research among undergraduates in a tertiary teaching hospital: a cross sectional questionnaire based study. J. Evolution Med. Dent. Sci. 2016;5(71): 5173-5175, DOI: $10.14260 /$ jemds/2016/1173

\section{INTRODUCTION \\ In the broadest sense of the word, the definition of research includes any gathering of data, information and facts for the advancement of knowledge. Medical research is the basic research, applied research or translational research conducted to aid and support the development of knowledge in the field of medicine. An important kind of medical research is clinical research, which is distinguished by the involvement of patients. Other kinds of medical research include pre- clinical research, for example on animals and basic medical research, for example in genetics. There have been dramatic and drastic changes in the era since the turn of the 21st century to date in medical research.}

Financial or Other, Competing Interest: None.

Submission 27-07-2016, Peer Review 22-08-2016,

Acceptance 27-08-2016, Published 03-09-2016.

Corresponding Author:

Dr. G. Rajeswaramma,

H. No: 45/24-B6, Ashok Nagar,

Kurnool-518005, Andhra Pradesh.

E-mail: dr.rajeswaramma@gmail.com

DOI: $10.14260 /$ jemds $/ 2016 / 1173$
The quality research in India is limited. As per the information available till 2008, India holds the twelfth rank among the productive countries in medicine research consisting of 65,745 articles with a worldwide publication share of $1.59 \% .1$ The medical education system in India does not incorporate research methodology as a part of the curriculum. It is seen that research programs in medical colleges get the rock bottom priority.

Every doctor should develop interest in medical research to give better quality treatment for patient as well as to update their knowledge. Right from their starting of medical education if we incorporate research methodology in their curriculum will enhance interest and knowledge on medical research. In this study, we conducted cross-sectional questionnaire-based study to know the awareness, knowledge and attitude of undergraduates on medical research.

\section{METHODOLOGY}

A cross-sectional study was conducted among 235 undergraduates of III and V semesters in November 2015. For this study, we prepared a questionnaire of 25 questions with 
yes or no options. Before giving this pre-validated questionnaire we explained about the study and given enough time to fill the questionnaire. Ethical committee approval and oral informed consent was taken.

This questionnaire explained awareness on research, knowledge about research and also projected attitude and reasons for not participating students in research.

\section{STATISTICS}

The data was expressed in percentage and was analysed using descriptive statistics.

\section{RESULTS}

\begin{tabular}{|c|c|c|c|}
\hline \multirow{2}{*}{$\begin{array}{l}\text { Sl. } \\
\text { No. }\end{array}$} & \multirow[t]{2}{*}{ Questions } & \multicolumn{2}{|c|}{$\begin{array}{r}\text { Response of } \\
\text { Students in \% }\end{array}$} \\
\hline & & Yes & No \\
\hline 1 & $\begin{array}{c}\text { Do you think that it is necessary } \\
\text { to know about research } \\
\text { as an undergraduate? }\end{array}$ & 98 & 2 \\
\hline 2 & Have you heard about ICMR? & 57 & 43 \\
\hline 3 & $\begin{array}{l}\text { Do you know about } \\
\text { Ethical committee? }\end{array}$ & 11 & 89 \\
\hline 4 & $\begin{array}{l}\text { Do you know about } \\
\text { Research protocol? }\end{array}$ & 8 & 92 \\
\hline 5 & $\begin{array}{l}\text { Do you know that who will give } \\
\text { approval for research projects? }\end{array}$ & 10 & 90 \\
\hline 6 & $\begin{array}{l}\text { Do you know about informed } \\
\text { consent in research? }\end{array}$ & 11 & 89 \\
\hline 7 & $\begin{array}{l}\text { Do you know that statistics are } \\
\text { necessary for research? }\end{array}$ & 91 & 9 \\
\hline 8 & $\begin{array}{c}\text { Have you heard about research } \\
\text { conferences and workshop? }\end{array}$ & 61 & 39 \\
\hline 9 & $\begin{array}{c}\text { Have you attended any } \\
\text { conference and workshop? }\end{array}$ & 8 & 92 \\
\hline 10 & $\begin{array}{c}\text { Have you presented any } \\
\text { poster/paper in conferences? }\end{array}$ & 2 & 98 \\
\hline 11 & Have you heard about journals? & 57 & 43 \\
\hline 12 & $\begin{array}{l}\text { Do you have any idea } \\
\text { about clinical trial? }\end{array}$ & 47 & 53 \\
\hline 13 & $\begin{array}{l}\text { Are you interested in } \\
\text { participating in research } \\
\text { projects? }\end{array}$ & 92 & 8 \\
\hline 14 & $\begin{array}{l}\text { Have you ever participated in } \\
\text { research projects? }\end{array}$ & 2 & 98 \\
\hline 15 & $\begin{array}{l}\text { Have you written any Research } \\
\text { paper of your projects? }\end{array}$ & 3 & 97 \\
\hline 16 & $\begin{array}{c}\text { Do you think MBBS curriculum } \\
\text { has given importance to } \\
\text { research? }\end{array}$ & 4 & 96 \\
\hline 17 & $\begin{array}{c}\text { Do you think that participating } \\
\text { in research will improve your } \\
\text { academic knowledge? }\end{array}$ & 46 & 54 \\
\hline 18 & $\begin{array}{l}\text { Do you think motivation for } \\
\text { research procedures is needed? }\end{array}$ & 100 & 00 \\
\hline 19 & $\begin{array}{c}\text { Do you have any idea about the } \\
\text { research procedures used as an } \\
\text { alternative to animal } \\
\text { experiments? }\end{array}$ & 90 & 10 \\
\hline 20 & $\begin{array}{c}\text { Do you have any information } \\
\text { about books, images and } \\
\text { research } \\
\text { designs produced? }\end{array}$ & 20 & 80 \\
\hline 21 & $\begin{array}{l}\text { Do you know about any } \\
\text { research reports? }\end{array}$ & 9 & 91 \\
\hline
\end{tabular}

\begin{tabular}{|c|c|c|c|}
\hline 22 & $\begin{array}{l}\text { Do you think that external } \\
\text { opportunities (Science } \\
\text { exhibitions, presentations, } \\
\text { competitions) improve } \\
\text { awareness regarding scientific } \\
\text { research? }\end{array}$ & 10 & 90 \\
\hline 23 & $\begin{array}{l}\text { Do you feel that practical } \\
\text { components influence ones } \\
\text { experience of UG research? }\end{array}$ & 98 & 2 \\
\hline 24 & $\begin{array}{l}\text { Are you aware of ongoing } \\
\text { research projects in your } \\
\text { institution? }\end{array}$ & 94 & 6 \\
\hline \multirow{6}{*}{25} & $\begin{array}{l}\text { What are the reasons that you } \\
\text { are not participating in research } \\
\text { a. Lack of awareness }\end{array}$ & 76 & 34 \\
\hline & b. Lack of knowledge & 53 & 47 \\
\hline & c. Lack of guidance & 90 & 10 \\
\hline & d. Lack of time & 33 & 67 \\
\hline & e. Lack of money & 40 & 60 \\
\hline & $\begin{array}{l}\text { f. } \quad \text { No need of } \\
\text { participating as an } \\
\text { undergraduate }\end{array}$ & 20 & 80 \\
\hline
\end{tabular}

Total 235 students participated in this study. All were from II year MBBS, Vth and IIIrd semester students. Almost $98 \%$ of students think that it is necessary to know about research as an undergraduate; $57 \%$ of students heard about ICMR. Only $10 \%$ of students know about Ethical committee, research protocol and inform consent; $91 \%$ of students agree that statistics were essential for research. Only $8 \%$ of students attended conference and $2 \%$ of students presented poster in conference; $3 \%$ of students wrote research protocol; $20 \%$ of students had information about books, images and research designs produced. Only $10 \%$ of students felt external opportunities (Science exhibitions, presentations, competitions) improve awareness regarding scientific research; $96 \%$ of students agreed that MBBS curriculum did not give an importance to research; $46 \%$ of students agreed that participating in research will improve your academic knowledge. Total $92 \%$ of students have interest in participating in research projects; $100 \%$ of students strongly agreed that motivation for research procedures was needed.

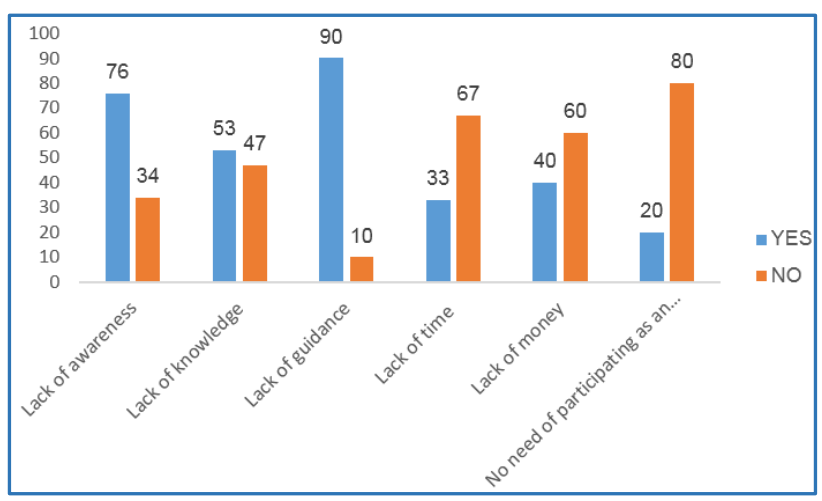

Graph 1: Showing the Reasons for Not Participating in Research

Graph showing that reasons for not participating in research $76 \%$ of students accepted that lack of awareness; $53 \%$ felt that lack of knowledge; $90 \%$ of students agreed that 
lack of guidance; $33 \%$ of students agreed that lack of time; $40 \%$ accepted because of lack of money. Only $20 \%$ of students thought that no need of participating as undergraduate.

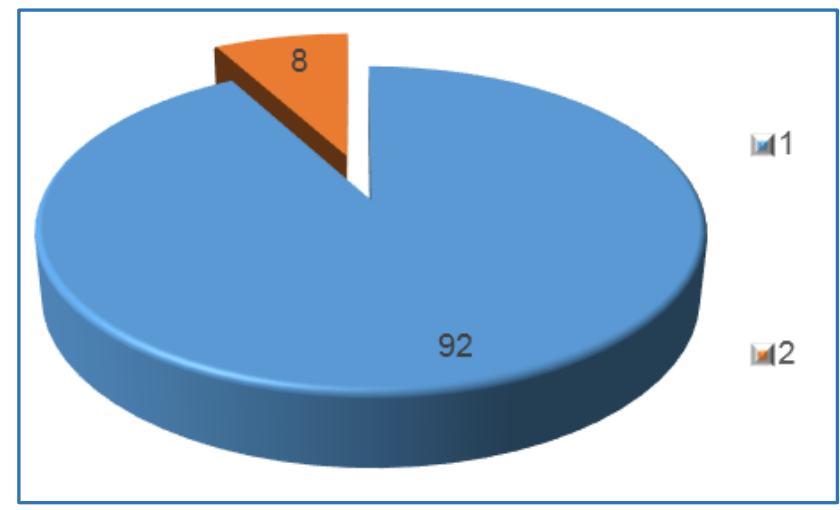

Graph 2: Showing Students' Interest in Participating in Research

Graph showing that total $92 \%$ of students were interested in participating in research. Only $8 \%$ of students were not inte rested in participating in research.

\section{DISCUSSION}

Undergraduate research is not a new phenomenon in medicine. Charles Best was a medical student at the time that he and his supervisor, Frederick Banting,2 discovered insulin. Insulin arises from the pancreatic islets of Längerhans, themselves discovered in 1869 by medical student Paul Längerhans.3 In biomedical research, Alan Hodgkin,4 formerly professor of biophysics at the University of Cambridge, won the Nobel Prize in 1972 for work on nerve transmission that he began as an undergraduate.

Worldwide day by day awareness and importance of research in medical education is increasing. In Germany, where research is an integral part of undergraduate medical curriculum; medical students were involved in $28 \%$ of the publications in a particular institution.5 A study reported that in a European country, Croatia, $23 \%$ of the undergraduate students were involved in research projects. 6 Especially in developing country like India, participation of undergraduate students in research is very limited.

We conducted this study to assess the awareness, knowledge and active participation of students in medical research. This study showed various key findings for not participating in medical research. Almost $92 \%$ of undergraduate students showed interest to participate in research. Only $10 \%$ of students know about Ethical committee, research protocol and inform consent. Only $8 \%$ of students attended conference and $2 \%$ of students presented poster in conference; $3 \%$ of students wrote research protocol.
Most of the students felt that MBBS curriculum did not give any importance to research. They strongly felt that motivation and guidance was also needed from the faculty. Very few students were not interested, because they thought that research did not improve their academic performance. Few of students thought lack of time and money. However, two studies that were carried out in Canada and Pakistan reflected a contrasting attitude of residents that a majority of time in residency should be spent learning the clinical aspects of their specialty and they were unwilling to sacrifice personal time for research.7,8

By this study we assessed that apart from student's interest, faculty plays a major role for active participation of student in research. Medical faculty should be trained for Research Methodology, Good Clinical Practices, Medical Ethics, Protocol Writing and Basic Statistics. So that they can motivate and create interest in participating research. Research experience may also boost the career profile of graduating medical students. By these ways, we can secure a future for academic medicine and foster a genuine respect for Evidence Based Medicine in tomorrow's doctors.

\section{CONCLUSION}

Students have enough awareness regarding research, but they need strong guidance and motivation by faculty to gain knowledge and to participate actively in research.

\section{REFERENCES}

1. Gupta BM, Bala A. A scientometric analysis of Indian research output in medicine during 1999-2008. J Nat Sci Biol Med 2011;2(1):87-100.

2. Frederick Grant Banting (1891-1941), codiscoverer of Insulin. Journal of the American Medical Association 1966;198(6):660-1.

3. Sakula A. Paul Langerhans (1847-1888): a centenary tribute. Journal of the Royal Society of Medicine 1988;81(7):414-5.

4. Hodgkin AL, Huxley AF. Action potentials recorded from inside a nerve fibre. Nature 1939;144(3651): 710-1.

5. Cursiefen C, Altunbas A. Contribution of medical student research to the Medline-indexed publications of a German medical faculty. Med Educ 1998;32(4): 439-40.

6. Kolcić I, Polasek O, Mihalj H, et al. Research involvement, specialty choice, and emigration preferences of final year medical students in Croatia. Croat Med J 2005;46(1): 88-95.

7. Silcox LC, Ashbury TL, VanDenKerkhof EG, et al. Residents' and program directors' attitudes toward research during anesthesiology training: a Canadian perspective. Anesth Analg 2006;102(3):859-64.

8. McCrindle BW, Grimes RB. Will pediatric residents do research? A survey of residents' attitudes. Ann R Coll Physicians Surg Can 1993;26:283-7. 